\title{
MEASURING THE IMPACT OF TRADE FINANCE ON COUNTRY TRADE FLOWS: A SOUTH AFRICAN PERSPECTIVE
}

\author{
Marcel Kohler \\ Deparment of Economics, University of KwaZulu-Natal
}

Adrian Saville

Gordon Institute of Business Science, University of Pretoria

Accepted June 2011

\begin{abstract}
Trade finance (or short-term credit) plays a crucial role in facilitating international trade yet is particularly vulnerable to financial crises as banks increase the pricing on all trade finance transactions to cover increased funding costs and higher credit risks. Whereas South Africa's financial institutions largely managed to strengthen their capital positions during the global financial crisis, the country's trade flows and access to capital (in particular trade finance and its costs) were hard hit by the crisis.

Little is known about the extent of shortages or 'gaps' in trade finance and the impact of this on South Africa's recent trade performance. Whilst our research recognises that access to trade finance is not the main cause of South Africa's trade contraction, our research suggests that all else equal, a one percentage point increase in the interbank lending rate of our trade partner could reduce exports by approximately ten per cent.
\end{abstract}

Key words: exports, trade finance, crisis

JEL: F10, 30

1

\section{Introduction}

The global financial crisis of 2008 originated in the housing markets of some of the world's more advanced economies, but its effects soon spread globally, resulting in 2009 recording the lowest rate of world economic growth since World War II. The financial nature of the crisis resulted in acute stress in capital markets, including markets for debt. Indeed, in many instances sources of credit evaporated or, where credit remained available, costs of debt financing soared. The depressed economic growth outcome manifested itself in a number of ways, including a sharp decline in international trade volumes, with the World Trade Organization (WTO) estimating that world trade decreased by twelve per cent in 2009 (WTO, 2010).

South Africa's trade flows did not escape the adverse effects of the global economic downturn. The country's imports and exports went from exhibiting positive growth in the third quarter of 2008 to negative growth rates in the following two quarters (Malouche, 2009). This trend continued until the third quarter of 2009, after which growth in import and export volumes and values showed some signs of recovery (South African Reserve Bank, 2010). South Africa is not alone in this respect. In a survey conducted by the World Bank, South Africa was amongst nine countries from a sample of 14 major trading countries that experienced a drastic decline in international trade in the wake of the crisis (WTO, 2009).

Standard economic analysis would suggest that this sharp contraction in the amount of trade is the result of demand-side effects (through lower business and consumer wealth as well as lower confidence amongst spenders and investors) and supply-side effects (through various liquidity constraints curtailing trade 
and investment activity). Whilst both the demand- and supply-side elements demand consideration, almost no empirical work has been undertaken to explore the relationship between trade finance and trade volumes. Thus, this paper gives consideration to supplyside explanations of international trade by focusing on the role of trade finance in facilitating international trade. In this fashion, this paper hopes to address the gap in the empirical work on trade-related financing in emerging markets by seeking to assess the impact of the increased cost of trade financing associated with the global financial crisis on South Africa's international trade activity to its top trading destinations. Against this backdrop, we believe this research represents one of the first attempts to assess the impact of the increased cost of trade financing associated with the global financial crisis. Given the preliminary nature of this research, we confine our study to the more simple consideration of export flows, rather than a more sophisticated consideration of import and export flows.

The rest of the paper is structured as follows. In Section 2 we present a brief review of the empirical literature followed by a discussion of the method and data used in Section 3. The empirical evidence is presented in Section 4 while the summary and the concluding remarks are presented in Section 5.

\section{2}

\section{An overview of the literature}

Liberal trade and financial policies together with technological progress have made international trade activity and developments in the financial sector engines of economic growth in modern global economies. The importance of international trade and financial flows is highlighted by their significant contributions to world output yearly. In general, international trade and financial sector liberalisation have brought enormous benefits to many countries and citizens. International trade has allowed nations to benefit from specialisation and economies to produce on a more efficient scale. It has raised productivity, supported the spread of technologies, knowledge and ideas, and enriched the range of choices available to consumers (WTO, 2010). Empirical studies support these assertions and show significant differences in the growth performance of open as opposed to closed economies (Sachs \& Warner, 1995; Wacziarg \& Welch, 2008). While an open trading and a liberal financial system generates considerable economic benefits, these systems are not independent of each other. International trade benefits strongly from a well developed and functioning financial environment and vice versa. By providing critical liquidity and security to enable the movement of goods and services, trade finance lies at the heart of the global trading system (Auboin \& Meier-Ewert, 2008). It is often reported that some 80 to 90 per cent of all international trade transactions are financed, although the source and evidence for this claim is unclear. What is clear from history, however, is that financial crises are among the most important causes of disruptions in international trade. As Pascal Lamy (2009) put it: “... today it is clear that trade is one of the casualties of this economic crisis and that we run the risk that one of the engines of growth - in fact, one that is very important for many developing countries stalls."

Berman and Martin (2009) help identify two specific transmission mechanisms through which international trade flows react to a financial crisis. On the demand side, an 'income effect' is identified to capture the change in demand for traded goods associated with the decreased consumption in countries affected by the down turn in economic activity during the crisis. In terms of supply, Berman and Martin (2009) identify a 'disruption effect' which has either a direct impact on international trade activity by reducing the amount of trade related credit available in the market, or alternatively takes on a more subtle form in that it increases the risk aversion associated with economic activity during the crisis.

Whilst economists have suggested a number of explanations for the most recent trade collapse, the consensus that has emerged, centers on a sharp contraction in global demand, namely an 'income effect', as the primary cause (WTO, 2010). According to the WTO's World Trade Report 2010 the impact 
of the 2008 global financial crisis on international trade was magnified by the product composition of the fall in demand, by the fact that the decline was synchronised across countries and regions, and by the growth of global supply chains in recent decades. Evidence from past financial crises, however establishes a causal link between reduced credit availability to traders and declining international trade levels. Examining performance by sector in 23 historical banking crises, Iacovone and Zavacka (2009) conclude that financial problems amplify the impact of negative demand shocks on exports. The authors find evidence of slower growth in export-oriented sectors that are reliant on external financing. This result supports the notion of a 'disruption effect'.

Berman and Martin (2009) estimate that the disruption effect could account for approximately nine per cent of the decrease in exports to countries hit by the global financial crisis. They estimate that this effect is even larger for African countries, measuring 23 per cent, and that the impact lasts up to seven years after a crisis. Arguably, this outcome is explained by the fact that firms in African countries respond differently to such disruptions because they use different financing instruments than others to fulfil their financing needs (Berman \& Martin, 2009). Specifically, rather than being insulated from the global financial crisis by having less developed financial sectors, firms in African countries tend to be more dependent on financing from the importing country, and are thus more vulnerable to a downturn in economic activity. In part, it is this dependence on external finance that Berman and Martin (2009) suggest, led to African exports being adversely affected by the global financial crisis.

Korinek, Le Cocguic and Sourdin (2010) identify a disruption effect similar to that of Berman and Martin (2009). Korinek et al. (2010) describe their disruption effect as consisting of a price effect and a volume effect. The price effect is primarily due to the general lack of liquidity in credit markets because of the absence of an interbank, or secondary, credit market. In turn, this results from the perceived counter-party risk amongst banks. In the case of the global financial crisis, this perception of risk drove up the overnight lending rate between banks to historically unprecedented levels, as shown by the 'TED spread' represented in Figure 1.

Figure 1

Relative cost of short-term financing (1990-2009)

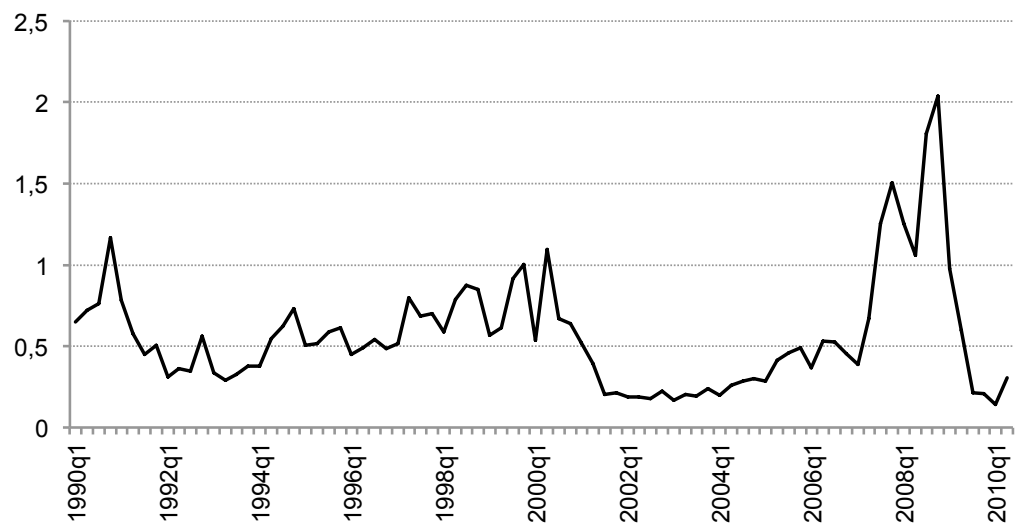

Source: Authors own calculations based on data from Thomson Reuters data stream

The increase in interest rate spreads, captured by the TED spread, represents a general increase in the cost of financing activities that resulted from the lack of liquidity in world credit markets that came to characterise the global financial crisis. 
The volume effect explains a decline in trade finance activity due to the reaction of financial institutions to the perceived risk in the market. On this score, financial institutions are assumed to respond to a perceived increase in risk in credit markets by attempting to reduce their risk exposure through the enforcement of stricter lending requirements as they seek to improve the quality of the assets on their balance sheets. In the case of the global financial crisis, the volume of credit activity also decreased due to the collapse of some financial institutions, leaving behind fewer market participants (Korinek et al., 2010). Korinek et al. (2010) find that shortterm lending to firms in the Organisation for Economic Co-operation and Development (OECD) countries did not decline by as much as lending to firms in non-OECD countries. However, they also found that during the period of the global financial crises short-term trade finance fell by less than general shortterm finance. It is arguable that this could be because of the relatively lower risk associated with trade finance.

Even though trade finance is typically short term and self liquidating in nature, the traded goods in question are often used as a form of collateral. Despite this, it remains the case that trade financing is hard hit in times of crisis. For example, at the peak of the Asian crisis (1997-1998), Argentina and Brazil experienced a 50 per cent drop in trade credits. In this vein, Korinek et al. (2010) find that during crisis, non-OECD countries experience a decline in short-term lending of four per cent more than OECD countries, which suggests that borrowers in developing countries are considered to pose a greater credit risk than borrowing firms in other countries.

The availability and cost of trade financing is strongly affected by four types of risks: economic or commercial risk, exchange rate risk, transportation risk and political risk. These risks associated with international trade are either much smaller or do not exist in domestic trade. Three factors determine the type of financial instrument chosen to deal with: the perception of the type and size of the risk involved in the transaction; the distribution of risk and risk reduction efforts between exporters, importers and their banks; and the costs of risk reduction (Fingerand \& Schuknecht, 1999). The most common forms of trade finance are letters of credit, domestic bank lending and inter-firm trade credit. Letters of credit are documents issued by the importer's bank - the issuing bank - and act as a means of assuring their commitment to pay the exporters. Once a letter of credit has been issued, the exporter can redeem payment by providing the required documentation to the confirming bank. However, for the funding mechanism to function properly, it is necessary that liquidity and confidence are maintained along the chain of payment from the importer to the exporter (Humphrey, 2009). Trade finance can also take the form of an extension of credit from domestic banks or inter-firm trade credit. Domestic bank lending occurs where banks in the home country extend credit to an exporter to finance the exporter's pre- or post-shipment costs. This capital is usually loaned against particular purchases and assets. By contrast, inter-firm trade credit arises through companies providing credit to each other when buyers delay or advance payments to sellers (Humphrey, 2009).

Although the absence of an adequate trade finance infrastructure as a barrier to trade is recognised in the literature (Fingerand \& Schuknecht, 1999; UNESCAP, 2005; Chauffour \& Farole, 2009; Gregory et al., 2010) little empirical work has been undertaken on the relationship between trade financing costs and international trade volumes specifically. Most of the research work undertaken in this area consists primarily of surveys and anecdotal data which points to the higher costs and in some cases decreased availability of trade finance during times of financial crises. An IMF-Bankers' Association for Finance and Trade (IMF-BAFT) survey of 44 banks from 23 developed and emerging markets reported a near doubling in the basis points spread over costs required to secure lines of credit or export credit insurance between October 2008 and January 2009 (IMF-BAFT 2009). The shortage of research work on the subject is most probably explained by the cost and difficulty involved in obtaining accurate information on such trade-related 
credit from the balance of payments of countries, as well as the fact that there are many trade financing tools and an assortment of ways in which trade financing is available to traders.

These limitations aside, Ronci (2004) contributed to the empirical literature by using changes in outstanding external short-term credit as a proxy for trade finance to consider how constrained trade financing affects trade flows on a panel of ten countries. However, this proxy is not without its drawbacks. For instance, the method does not take into account intra-firm finance or trade related to foreign direct investment (Ronci, 2004). Thomas (2009) helpfully built on Ronci's (2004) work by including the net financial flows to emerging markets as an additional proxy for trade finance and by using a larger panel of 22 countries. Importantly, Ronci (2004) and Thomas (2009) find that trade volumes are affected positively by four common factors, namely: financial conditions; the availability of trade finance; relative prices; and changes in income. However, it was also found that whilst the availability of trade finance is a significant explanatory factor, it accounted for only a small portion of the variability in trade flows.

Whilst making important contributions to the empirical literature, the findings of Ronci (2004) and Thomas (2009) have shed little light on how firms in emerging markets may be affected by the availability of trade credit. According to Humphrey (2009) it is unclear exactly how emerging markets will be affected. While it is argued that emerging markets have benefited from large capital inflows from developed nations, it is suspected that in times of crisis these flows dry up, thereby adversely effecting the ability of firms in emerging markets to finance international trade.

The banking systems of emerging countries also are relatively underdeveloped. This may have protected banks in emerging countries from importing the toxic securities that have plagued the balance sheets of many developed nations' banks. Humphrey (2009) suggests that this insulation may go some way in mitigating the effects of global financial crisis thus allowing domestic banks to continue servicing their clients. However, in a different approach, it is this underdevelopment that Berman and Martin (2009) suggest may leave a developing nation in a more vulnerable position. These underdeveloped banking systems, unable to supply enough credit to their domestic exporters, may result in firms in emerging markets relying on lines of credit derived from the importing country. This would leave the exporters in the developing country vulnerable to liquidity concerns in the importing country.

In this vein, Chor and Manova (2009) consider the role that interbank lending rates play in determining a country's ability to export. This was done by analysing monthly import data for the US and the interbank lending rate in exporting countries. Their estimates found that a one per cent increase in the interbank lending rate is associated with an average 16 per cent decrease in trade volumes. As identified by Chor and Manova (2009), exporting activities have fixed and variable costs. The variable exporting costs include expenses such as shipping, insurance, duties and working capital. In a well-functioning financial system, exporters may turn to the domestic banks to finance these activities until such time as the revenues from the trade are earned. However, if the financial sector of the exporting country is not well developed, the exporter may be forced to rely on the financial institutions of the importing country for financing, as suggested by Berman and Martin (2009).

In the next section of this paper, we attempt to build on the work of Berman and Martin (2009) by setting out in our research the method and data employed to examine the hypothesis that traders in developing countries are dependent on the cost and availability of finance in the financial systems of their trading partners. We also adapt the approach employed by Chor and Manova (2009) to estimate a country-specific trade model. In this regard, we make use, inter alia, of South Africa's export flows to the country's major trading partners and the interbank lending rates of these countries (which serves as a proxy for the cost of trade finance) to explore the arguments set out above. By adapting the basic model of Chor and Manova (2009) to account 
for the cost of credit in the importing country, we endeavour to estimate the impact of changes in trade credit costs on South Africa's exports.

\section{3}

\section{Method and data}

To assess the impact of the global financial crisis on South Africa's exports through its effect on the availability of trade credit, we employ monthly data for South Africa's exports to its top 20 exporting destinations by value. ${ }^{2}$ As expected following the collapse of Lehman Brothers in September 2008, the value of South African exports to its major trading partners fell considerably.

Figure 2

Monthly rand value of South African exports (2006-2010)

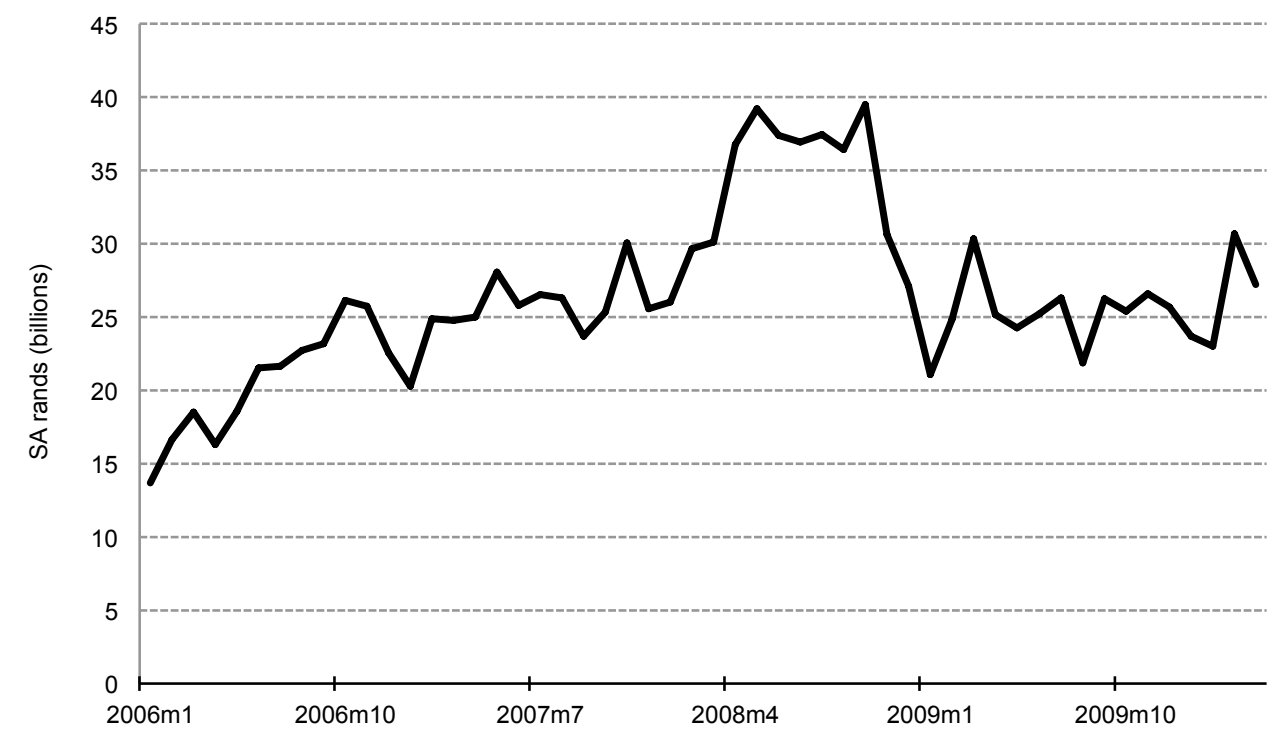

Source: Department of Trade and Industry, South Africa

In this study we examine the cost of credit in the importing country as an explanatory factor in the fall in South African exports during the global financial crisis. A direct measure of the cost of trade finance, such as the rates charged on export credit lines or insurance, would be ideal, but such data are not easily available for a large sample of countries. Following Chor \& Manova (2009), we use the one-month interbank lending rate in the importing country as a proxy for the cost of short-term trade finance. ${ }^{3}$ There are pros and cons to using the interbank rate as an indicator of credit conditions. One advantage is that it is available for a relatively large number of countries, which includes both developed and a good number of trade-dependent emerging econo- mies. However, a key qualification is that it is a meaningful measure of the cost of credit only in economies with fairly developed banking sectors, where there is an active interbank lending market. As far as lending rates goes, the one-month interbank lending rate constitutes a good general indicator of the cost of credit as it represents the rate at which commercial banks are willing to lend to one another to satisfy their reserve requirements and in adjusting their liquidity positions. For this reason, the one-month interbank lending rate is generally accepted as an indicator of the overall cost of credit within an economy. Moreover, other interest rates within an economy often are influenced by the onemonth interbank lending rate or even pegged to 
the rate. Whilst, it is recognised widely that, in normal economic times, an increase in the interbank lending rate may indicate either limited credit availability or excess demand for credit, during times of a financial crisis, a rise in this rate is assumed to indicate a tightening in the supply of credit (Chor \& Manova, 2009). Furthermore, there is a growing body of empirical work based on micro-level data which shows that more credit-constrained firms do indeed have a lower propensity for undertaking exporting activities; see Amiti and Weinstein (2009) and Minetti and Zhu (2009) in this respect.

Figure 3 shows the interbank lending rates in the markets of South Africa's five largest export destinations for the period 2006 to 2009. At least three features are evident. First, a spike occurs early in the data series. This corresponds with the extreme jump in the London Interbank Offered Rate (LIBOR) overnight indexed swap (OIS) spread which occurred in August 2007 in advanced economies, in this case represented by the US and UK markets, that Taylor and Williams (2008) describe as a 'black swan in the money market'. The Chinese interbank lending rate spiked with a modest delay, but the jump remains significant.

Figure 3

Interbank lending rates (\%) in South Africa's trade partners (2006-2009)

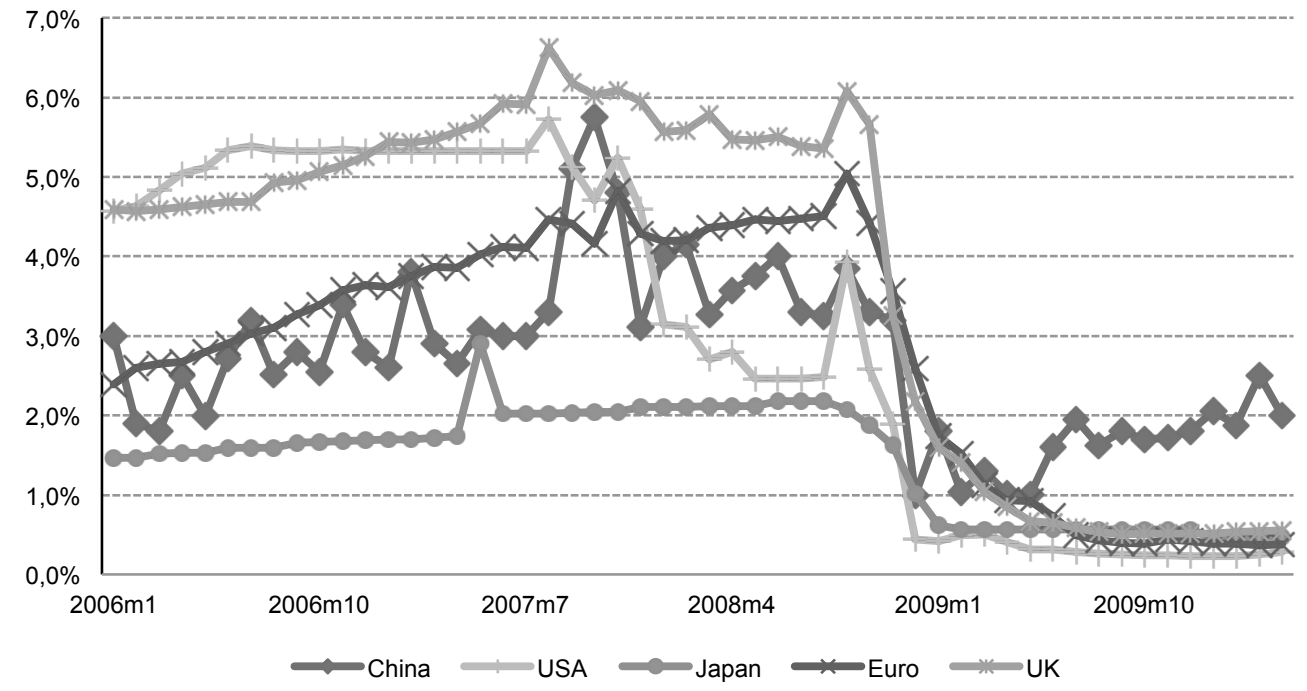

Source: Thompson Reuters DataStream database

Second, following these initial disturbances, the one-month interbank lending rates in China, the US and the UK began decreasing until the collapse of Lehman Brothers in September 2008. By contrast, interbank lending rates in Japan and the Euro zone continued to tighten.

Third, following the second spike in interbank lending rates, central banks sought to reduce the cost of borrowing. The actions of the various monetary authorities reduced key interest rates on average to approximately one per cent, although China ran a somewhat tighter monetary policy stance amidst concerns of its economy overheating despite the dampening impacts of the global financial crisis.

History and data descriptions aside, to empirically test the hypothesis that a relationship exists between trade flows and the availability (or cost) or trade finance, we control for two additional factors, namely:

1) the Rand-US Dollar exchange rate, which is included as a proxy for 'price competitiveness' of South African exports; $;^{4,5}$ and 
2) quarterly gross domestic product (GDP) levels in export markets, measured in domestic currency, which is used as a proxy for demand conditions in South Africa's export markets. ${ }^{5}$

In the development of our model we have adapted the approach of Chor and Manova (2009) in estimating a counties trade flows as a function of interest rates. Our method reflects that of Berman and Martin (2009) in that we hypothesise that a crisis may affect the exports of a developing country, in this case South Africa, through the pressure on the financial systems in the importing country. To test this, we construct an equation that holds that the value of South Africa's exports to an importing country, denoted by a subscript $c$ at time $t$, is a function of the interest rate (namely, the one-

$$
\ln X_{c t}=\beta_{1} \text { RATE }_{c t}+\beta_{2} D_{\text {crisis }} \times R_{A T E}+D_{t}+\varepsilon_{c t}
$$

In order to account for exchange rate fluctuations, which may influence the demand for exports, we extend the analysis to include a variable which captures changes in competetiveness arising from fluctuations in the rand/US dollar spot exchange rate. In addition, so as to isolate the effect of supply side trade financing factors we control for the variation in demand in South Africa's export markets. We incorporate quarterly GDP data in our analysis by holding the value of the quarterly data constant over that quarter's constituent months. In so doing, we effectively control for demand variation by introducing a time month interbank lending rate) in the importing country, as captured by the $R A T E_{c t}$ variable. As with Chor and Manova (2009) we include $D_{t}$ as a time-fixed effect in an attempt to capture the time-series variation in the aggregate demand for South Africa's exports. In addition, as in Berman and Martin (2009), we introduce a dummy variable, $D_{\text {crisis }}$, into the analysis to capture the effect of the global financial crisis in the relationship by interacting it with the interest rate variable. $\beta_{1}$ and $\beta_{2}$ capture the variation in exports associated with the cost of credit with $D_{\text {crisis }}$ taking on a value of zero prior to the crisis and a value of one from September 2008 onwards. The simplified version of our model is captured in Equation 1.

(Equation 1)

specific, namely, monthly fixed effect into the analysis. This effectively assumes that monthly variation in South Africa's export demand is negligible. This is a reasonable assumption given that the quarterly variation in the GDP data is extremely small. These additions result in an extension of our model. The extended model is represented by Equation 2 which incorporates both the SA rand/US dollar spot exchange rate, $C U R R_{t}$ and the $\log$ of the constant trade partner monthly GDP, $L N G_{c t}$ as additional explanatory variables in the analysis.

$$
\ln \mathrm{X}_{\mathrm{ct}}=\beta_{1} \mathrm{RATE}_{\mathrm{ct}}+\beta_{2} \mathrm{D}_{\mathrm{crisis}} \times \mathrm{RATE}_{\mathrm{ct}}+\beta_{3} \mathrm{CURR}_{\mathrm{t}}+\beta_{4} \mathrm{LNG}_{\mathrm{ct}}+\mathrm{D}_{\mathrm{t}}+\varepsilon_{\mathrm{ct}}
$$

(Equation 2)

4

\section{Empirical results}

The coefficients of the equations in our model were initially estimated using ordinary least squares with data spanning the period January 2006 to March 2010. Standard diagnostic tests were carried out on our modelled results. The presence of heteroskedasticity was confirmed using the Breusch-Pagan/Cook-Weisberg test. Tests for autocorrelation and the inspection of estimated results for multicollinearity both came back negative. The method of generalised least squares with both monthly and country specific fixed effects was then applied to re-estimate the results of our model. These results are summarised in Table 1. Specifically, Table 1 captures estimates for each of the coefficients for the variables included in the two modelled equations, with standard errors shown in parenthesis.

From our initial regression results, that is Equation 1 without a dummy variable included, we found a statistically significant negative relationship between the one-month interbank rate and export volumes. These 
results are not reported. With the inclusion of the 'crisis' dummy variable as in Equation 1, the results show that the pre-crisis relationship between interbank lending rates and exports is weaker than after the crisis. Specifically, the results imply that a one per cent rise in interest rates reduces exports by up to 10 per cent after the crisis and about seven per cent before the crisis. These results are consistent with Chor and Manova's (2009) findings and are in line with our expectations. When we included the exchange rate as part of our analysis, we find that the exchange rate is significant in explaining export values, and accounts for about five per cent of the variation in exports over the survey period, ceteris paribus. In estimating Equation 2 we include the $\log$ of monthly GDP using a constant (LNGC) transformation of the quarterly GDP data to account for the effect of changes in demand on the levels of exports. Our extended model remains robust yielding statistically significant results. As suggested by our initial estimated model results in the form of the more simplified Equation 1, an increase in interbank lending rates is thus shown to reduce South African exports. Specifically, the results suggest that a one percentage point increase in lending rates ceteris paribus reduces South African exports by 11.2 per cent. As can be seen from Table 1, this is not substantially different to our initial regressions results.

Finally, since significant time delays are often experienced in trading goods internationally particularly the time between when traded goods are received and when they are paid for, we also re-estimated the equations in our model by replacing the interbank lending rate, $R A T E_{c t}$ with its values lagged by one period, RATE $1_{c t}$. Whilst such time delays explain why the lending rate in the previous period may affect exports in the current period, the re-estimated results using the lagged interbank lending rates were very similar to the original estimates and hence did not warrant reporting them separately.

Table 1

Estimation results

\begin{tabular}{|c|c|c|c|c|}
\hline \multirow{2}{*}{ Dependent Var $(\operatorname{InX})$} & \multicolumn{4}{|c|}{ Estimated Equation } \\
\hline & POLS(1) & FGLS(1) & POLS(2) & FGLS(2) \\
\hline RATE & \multirow{4}{*}{$\begin{array}{l}-\mathbf{0 . 1 0 4 8} \\
(0.013) \\
-0.0499^{* *} \\
(0.023)\end{array}$} & \multirow{5}{*}{$\begin{array}{l}-\mathbf{0 . 0 6 9 8} 8^{\star *} \\
(0.008) \\
-0.0317^{\star *} \\
(0.012)\end{array}$} & \multirow{2}{*}{$\begin{array}{l}-0.1165^{\star *} \\
(0.014) \\
-0.0399 \\
(0.025)\end{array}$} & $\begin{array}{l}-0.0766^{* *} \\
(0.009)\end{array}$ \\
\hline Crisis dummy & & & & $\begin{array}{l}-0.0357^{\text {** }} \\
(0.012)\end{array}$ \\
\hline CURR & & & $\begin{array}{l}\mathbf{0 . 0 3 0 5}^{\text {** }} \\
(0.007)\end{array}$ & $\begin{array}{l}\mathbf{0 . 0 5 2 5}^{\text {** }} \\
(0.007)\end{array}$ \\
\hline \multirow[t]{2}{*}{ LNG } & & & $0.0459^{* *}$ & $0.0294^{* *}$ \\
\hline & & & $(0.012)$ & $(0.011)$ \\
\hline Monthly fixed effects & yes & \multirow{2}{*}{$\begin{array}{l}\text { yes } \\
884\end{array}$} & yes & yes \\
\hline Observations & 884 & & 689 & 687 \\
\hline R-squared & 0.203 & & 0.286 & \\
\hline Adj R-squared & 0.152 & & 0.231 & \\
\hline Wald $\operatorname{chi}^{2}(2)$ & & $99.49^{* * *}$ & & \\
\hline Wald $\operatorname{chi}^{2}(4)$ & & & & $253.37^{* \star *}$ \\
\hline
\end{tabular}

POLS is pooled ordinary least squares, FGLS is full generalised least squares

To summarise, our estimation results are consistent with our expectations. The results suggest that during the global financial crises the increased cost of financing trade activity, as measured by the cost of interbank credit in the importing country, had a notable influence on South African exports. Specifically, the results suggest that a one percentage point increase in the interbank lending rate could reduce exports by approximately ten per cent, all else equal. Moreover, not only are higher interest rates associated with lower export 
volumes, this trend has been exaggerated since the onset of the global financial crisis.

\section{5}

\section{Qualifications}

Before arriving at any conclusions, two factors deserve attention.

Firstly, in this investigation we have used aggregate export data. Whilst we are of the view that this is useful at the early stages of investigation, we acknowledge that this approach fails to answer questions about the sensitivity of specific export sectors to the availability of credit. This is an important point, as Ronci (2004) found that different sectors responded with varying degrees of sensitivity to changes in the availability of trade finance. The use of more detailed export data may take us some way towards quantifying the sensitivity of South Africa's export sectors to increases in the cost of trade finance. We leave this and other issues to future research.
Secondly, the cost of domestic credit has been omitted from the above inquiry. The omission was partly based on the a priori assumption that a developing country with an underdeveloped financial sector will rely upon the financial system of its trading patter to obtain trade finance. This assumption is, perhaps too strong for the South African economy, which arguably has a developed financial sector that has fared relatively well in light of the crisis. As a result of the developed nature of South Africa's financial system it is possible that exporters may also rely upon the domestic credit market for obtaining trade finance.

In an attempt therefore to control for the omission of the effects of domestic finance costs on the volume of South Africa's exports, an alternative specification of the model has been estimated. The domestic cost of credit variable (SARATE) measured by the South African interbank lending rate is introduced as an additional explanatory variable in Equation 3.

$$
\ln \mathrm{X}_{\mathrm{ct}}=\beta_{1} \mathrm{RATE}_{\mathrm{ct}}+\beta_{2} \mathrm{D}_{\mathrm{crisis}} \times \mathrm{RATE}_{\mathrm{ct}}+\beta_{3} \mathrm{CURR}_{\mathrm{ct}}+\beta_{4} \mathrm{LNGS}_{\mathrm{t}}+\beta_{5} \mathrm{SARATE}_{\mathrm{t}}+\mathrm{D}_{\mathrm{t}}+\varepsilon_{\mathrm{ct}}
$$

(Equation 3)

The inclusion of the SARATE has no significant effect on our results. The coefficient on the SARATE variable is of concern, however. Being positive and significant, the result suggests that higher costs of domestic finance are associated with increased South African export volumes. At first glance this is a counterintuitive result. We suspect that this positive correlation between exports and the cost of credit may be an artefact of the South African Reserve Bank's (SARB) response to the inflationary pressures felt within the economy. We note here that for the immediate period prior to the global financial crisis the SARB had been increasing interest rates in response to inflationary pressures. In fact, over the initial period of our investigation the South African economy was also experiencing strong aggregate demand (driven in part by rising export demand) which the SARB was trying to curtail in its efforts to reign in domestic inflation. With the onset of the global financial crisis, however, the SARB started to decrease domestic interest rates as mediumterm inflation projections became more favourable. This move was made possible by the decrease in commodity prices as well as the reduction in household consumption demand which ensued with the crisis (Mboweni, 2008). We further note that, over the period under investigation, South African inflation was always beyond the upper bound of the SARB's announced target. Given the domestic interest rate represents the preferred tool utilised by the reserve bank to control inflation, it is likely that rate changes in the past were at least in some part the SARB's response to the inflationary pressures coming from the rising export and aggregate demand in the economy (Kahn, 2008). This would go some way in explaining the positive coefficient we estimate for the SARATE variable. 


\section{Table 2}

Estimation results with the inclusion of domestic credit costs

\begin{tabular}{|c|c|c|}
\hline \multirow{2}{*}{ Dependent Var $(\operatorname{In} X)$} & \multirow[b]{2}{*}{ POLS(3) } & \multirow[b]{2}{*}{ GLS(3) } \\
\hline & & \\
\hline \multirow[t]{2}{*}{ RATE } & $-0.116^{* *}$ & $-0.078^{\star \star}$ \\
\hline & $(0.014)$ & $(0.011) 4$ \\
\hline \multirow[t]{2}{*}{ Crisis dummy } & -0.040 & $-0.038^{* *}$ \\
\hline & $(0.025)$ & $(0.010)$ \\
\hline \multirow[t]{2}{*}{ CURR } & $0.032^{\star *}$ & $0.029^{\star *}$ \\
\hline & $(0.007)$ & $(0.005)$ \\
\hline \multirow[t]{2}{*}{ LNGS } & $0.046^{* *}$ & $0.052^{* *}$ \\
\hline & $(0.011)$ & $(0.009)$ \\
\hline \multirow[t]{2}{*}{ SARATE } & 0.200 & \\
\hline & 0.053 & \\
\hline \multirow[t]{2}{*}{ RR } & & -0.23129 \\
\hline & & $(0.026)$ \\
\hline Monthly fixed effects & Yes & Yes \\
\hline Observations & 687 & 687 \\
\hline R-squared & 0.290 & \\
\hline Adj R-squared & 0.236 & \\
\hline Wald $\operatorname{chi}^{2}(5)$ & & $462.81^{\star * *}$ \\
\hline
\end{tabular}

POLS is pooled ordinary least squares, FGLS is full generalised least squares

In an attempt to account for any bias that the high inflation environment in South Africa may have had on our investigation and its results, the real interest rate $(\mathrm{RR})$ is considered as an alternative to the nominal rate (SARATE) for the cost of domestic credit variable. Our results remain robust under this scenario with the coefficient on the real interest rate variable now negative and significant at the 10 per cent level. This result conforms closely to expectations indicating that an increase in the cost of domestic credit ceteris paribus results in a decrease in the country's exports. Importantly the inclusion of domestic credit cost measures as part of our analysis does not compromise any of our findings. Coefficient values and significance levels remain robust despite the presence of the South African interbank lending rate as a control variable.

\section{6}

\section{Concluding remarks}

The global financial crisis brought about the sharpest decline in global economic growth since World War II and, with it, acute stress in global financial markets. Whilst the slowdown in international trade that accompanied the global financial crisis might be explained by a number of factors, our hypothesis is that access to trade credit and, more specifically, the cost of credit, stands out as a key explanatory factor.

In this regard, the results of our research efforts are broadly consistent with findings of previous studies. Specifically, we find that an increase in the interbank lending rate, which represents a tightening of trade finance, reduces exports substantially. This is in line with the key findings of Chor and Manova (2009). It was also shown that South African exports appear to be heavily influenced by credit conditions in the exporting country. This is consistent with Berman and Martin (2009). Whilst these findings represent new information with regard to the performance of South Africa's export sector, the results can be advanced in a number of ways. The use of more detailed export data as well the inclusion of variables controlling for the export demand and exchange rates should help isolate the effect of rising credit costs on specific export sectors, and is a subject for future study. What 
is clear, however, is that developing countries such as South Africa are vulnerable to constrained finance resulting from financial crises, which may consequently have a material impact on the performance of the export sector of the economy.

\section{ENDNOTES}

1 The TED spread represents a measure of the cost of short-term credit as it measures the difference between the US Treasury Bill interest rate and the London Interbank Offer Rate (LIBOR) (Ferson \& Harvey, 1993).

2 Trade data are obtained from South Africa's Department of Trade and Industry.

3 The interbank lending rate data was obtained from Thomson Reuters DataStream database. The rates used are those of the respective importing country quoted by the central bank.

4 Although conventional wisdom holds that currency weakness promotes export competitiveness through price action, Saville (2010) offers an alternative view in the form of evidence that shows that South Africa's manufacturers, and specifically manufactured exports, do better in periods of Rand strength as opposed to Rand weakness. The argument is noted here, but not explored further.

5 The exchange rate data were obtained from DataStream; and the GDP data are sourced from the International Monetary Fund's databases.

\section{Acknowledgement}

The authors gratefully acknowledge both the Gordon Institute of Business Science and Economic Research Southern Africa for providing financial assistance towards this research.

\section{References}

AMITI, M. \& WEINSTEIN, D. 2009. Exports and financial shocks. Columbia University mimeo. AUBOIN, M. \& MEIER-EWERT, M. 2008. Improving the availability of trade finance during financial crises. WTO Publications: Geneva.

BERMAN, N. \& MARTIN, P. 2009. The vulnerability of sub-Saharan Africa to the financial crisis: the case of trade. Preliminary draft, May 2009. Prepared for the conference on financial markets, adverse shocks and policy responses in fragile countries; Accra, Ghana, May 21-23 2009.

CHAUFFOUR, J. \& FAROLE, T. 2009. Trade finance in crisis: market adjustment or market failure. World Bank Policy Research Working Paper 5003, Washington DC.

CHOR, D. \& MANOVA, K. 2010. Off the cliff and back? Credit conditions and international trade during the global financial crisis. Available at: VOX, www.voxeu.org.

DORSEY, T. 2009. Trade finance stumbles. International Monetary Fund, Finance and Development, March 2009, Washington DC.

FERSON, W.E. \& HARVEY, C.R. 1993. The risk and the predictability of international equity returns, Review of Financial Studies, 6(3):527-566.

FINGERAND, K.M. \& SCHUKNECHT, L. 1999. Trade, finance and financial crises. WTO Special Studies 3, WTO Publications: Geneva.

GREGORY, R., HENN, C., MCDONALD, B. \& SAITO, M. 2010. Trade and the crisis: protect or recover. IMF Staff Position Note SPN/10/07. IMF: Washington DC.

HUMPHREY, J. 2009. Are exporters in Africa facing reduced availability of trade finance. Institute of Development Studies, Brighton.

IACOVONE, L. \& ZAVACKA, V. 2009. Banking crises and exports: lessons from the past. World Bank Policy Research Working Paper No. 5016.

IMF-BAFT. 2009. IMF-BAFT Trade finance survey: a survey among banks assessing the current trade finance environment. Available at: http://baft.org/content folders/ Issues/ IMFBAFT SurveyResults20090331.ppt.

KAHN, B. 2008. Challenges of inflation targeting for emerging-market economies: the South African case. Challenges for Monetary Policy-Makers in Emerging Markets. South African Reserve Bank.

KORINEK, J., LE COCGUIC, J. \& SOURDIN, P. 2010. The availability and cost of short-term trade finance and its impact on trade. OECD Trade Policy Working Papers, No. 98. OECD Publishing.

LAMY, P. 2009. Remarks at the United Kingdom's Department of International Development, January 22, 2009. 
MALOUCHE, M. 2009. Trade and trade finance developments in 14 developing countries post September 2008: a World Bank survey. Policy Research Working Paper No. 5138. World Bank: Washington DC.

MBOWENI, T.T. 2008. Monetary policy, inflation targeting and inflation pressures. Bank for International Settlements. 22 May 2008. Available at: www.bis.org/review/r090603c.pdf (accessed 2010-10-20).

MINETTI, R. \& CHUN ZHU, S. 2009. Credit constraints and firm export: microeconomic evidence from Italy. Michigan State University mimeo.

RONCI, M. 2004. Trade finance and trade flows: panel data from 10 crises. International Monetary Fund Working Paper, WP/04/225.

SACHS, J.D. \& WARNER, A. 1995. Economic reform and the process of global integration, Brookings Papers on Economic Activity, 1:1-118.

SAVILLE, A.D. 2010. Cents and sensibility: why a weak Rand may not help South African manufacturers. Cannon Asset Managers: Spring 2010.

SOUTH AFRICAN RESERVE BANK. 2010. Quarterly Bulletin: March 2010. Available at: www.reservebank.co.za/internet/Publication.nsf/LADV/92A620ACD595CF 42422576EB00555EF5/\$File/QBMarch2010.pdf (accessed: 2010-06-10).

THOMAS, A. 2009. Financial crises and emerging market trade. Strategy, Policy and Review Department, International Monetary Fund: Washington DC.

Thomson Reuters DataStream database. Accessed: 2010-06-10.

TAYLOR, J.B. \& WILLIAMS, J.C. 2008. A black swan in the money market. Working Paper. No. 2008-04. Federal Reserve Bank of San Francisco.

UNITED NATIONS. 2005. Trade finance infrastructure development handbook for economies in transition. UNESCAP: New York.

WACZIARG, R. \& WELCH, K.H. 2008. Trade liberalization and growth: new evidence. World Bank Economic Review, 22 (2):187-231.

WORLD TRADE ORGANIZATION. 2009. Overview of the developments in the international trading environment. Annual Report by the Director General. WT/TPR/OV/12. 18 November 2009.

WORLD TRADE ORGANIZATION. 2010. World Trade Report 2010. WTO publications: Geneva. 